\title{
ANALISIS KOMUNIKASI BISNIS ONLINE SHOP MANTAN KARYAWAN MELALUI MEDIA SOSIAL INSTAGRAM
}

\author{
Eceh Trisna Ayuh ${ }^{1}$, Hafri Yuliani \\ Universitas Muhammadiyah Bengkulu ${ }^{1,2}$ \\ Ecehtrisna@umb.ac.id ${ }^{1}$
}

\begin{abstract}
ABSTRAK
Tujuan penelitian untuk mengetahui komunikasi bisnis online shop mantan karyawan melalui media sosial instagram. Metode penelitan menggunakan metode deskriptif kualitatif dilengkapi dengan referensi media online. Hasil penelitian menunjukkan; 1. Product, produk yang ditawarkan oleh online shop dapat di update secara langsung melalui foto terbaru, live streaming, instastory, serta video; 2. Price, publikasi melalaui media sosial Instagram, membuat semua konsumen dapat mengetahui langsung harga dan diskon yang ditawarkan oleh online shop; 3. Place, instagram menjadikan setiap individu dapat membuka toko secara online tanpa harus memiliki tempat penjualan. 4. Promotion, promosi yang dilakukan online shop sangat mudah, seperti live streaming karena tidak harus mengeluarkan biaya, selain itu pembuatan video dan dishare kesemua followers bisa secara langsung dilakukan. Simpulan penelitian bahwa instagram sebagai media promosi telah mampu memberikan ruang untuk bisa mempromosikan semua produk. Simpulan penelitian bahwa komunikasi mantan karyawan dalam bisnis online shop sudah mulai berkembangan sehingga menstimulus masyarakat di daerah untuk bisa bersaing tidak hanya menciptakan toko secara konvensional tetapi toko secara online.
\end{abstract}

Kata Kunci: Komunikasi Bisnis, Place, Price, Produk, Promosi

\begin{abstract}
The purpose of the study was to determine the online shop business communication of former employees through Instagram social media. The research method uses a qualitative descriptive method equipped with online media references. The results showed; 1. Products, products offered by online shops can be updated directly through the latest photos, live streaming, stories, and videos; 2. Price, publication through Instagram social media, allows all consumers to know firsthand the prices and discounts offered by online shops; 3. Place, Instagram allows every individual to open an online store without having to have a place of sale. 4. Promotion, promotions carried out by online shops are very easy, such as live streaming because they do not have to cost money, besides making videos and sharing them with all followers can be done directly. The conclusion of the study is that Instagram as a promotional media has been able to provide space to be able to promote all products. The conclusion of the study is that the communication of former employees in the online shop business has begun to develop so that it stimulates the community in the area to be able to compete not only in creating conventional stores but online stores.
\end{abstract}

Keyword: Bisnis Communication, Place, Price, Product, Promotion 


\section{PENDAHULUAN}

Perkembangan teknologi yang semakin canggih membuat persaingan bisnis melalui media sosial semakin meningkat. Terlihat dari meningkatnya pengguna media sosial. Pengguna media sosial dari orangtua, dewasa, remaja bahkan sampai anak-anak telah memiliki akun media sosial. Berdasarkan sumber Digital Around The World in 2020 menjelaskan bahwa Total Populasi (Jumlah penduduk): 7,750 milyar, Pengguna Mobile Unik: 5,190 milyar, Pengguna Internet: 4,540 milyar, Pengguna Media Sosial Aktif: 3,800 milyar. Tidak jauh berbeda dengan hasil survei APJII bahwa jumlah pengguna internet di Indonesia hingga kuartal II tahun 2019 mencapai $73,7 \%$ dari populasi atau setara 196,7 Juta pengguna. Hampir tembus 200 juta pengguna dari Populasi RI yang 266,9 Juta. (Data BPS, 2019). Artinya bahwa masyarakat Indonesia bisa dikatakan sudah melek media. Salah satu media sosial yang focus pada bisnis yaitu Instagram. Pertengahan tahun 2016 Instagram secara resmi mengumumkan pembaharuan dan penambahan fitur bisnis pada instagram. Peluncuran fitur baru berdasarkan beberapa keberhasilan pebisnis yang memanfaatkan Instagram sebagai media bisnis.

Kecanggihan yang ditawarkan oleh media sosial Instagram telah mengubah budaya masyarakat, yang tadinya hanya berjualan secara konvensional tetapi dengan media sosial saat ini telah menstimulus masyarakat untuk bisa menciptakan online shop di media sosial. Artinya dengan media sosial instagram telah merubah budaya masyarakat, yang sebelumnya harus membuka toko secara real, tetapi dengan instagram telah menghemat baik secara biaya sewa toko maupun jangkauan untuk bisa menjangkau konsumen. Tidak hanya itu, tidak harus datang langsung ke toko, tetapi konsumen bisa langsung memesan dan menerima barang dirumah. Ditambah lagi pembayaran yang secara online semakin mempermudah konsumen dalam bertransaksi penjualan. Semua kemudahan yang ditawarkan oleh media sosial instagram, telah mempermudah komuniaksi bisnis bagi penjual atau reseller, karena untuk promosi online shop dengan mudah bisa langsung memposting melalaui instastory yang langsung bisa tag atau menandai teman atau konsumen. Kemudian foto-foto produk terbaru bisa di publis setiap saat ditambah lagi dengan price yang langsung di tawarkan lengkap dengan diskonnya.

Artinya marketing mix yang ditawarakan pemilik online shope sangat dipermudah dengan menggunakan media sosial instagram. Sehingga komuniaksi bisnis yang dibangun bisa dengan mudah menjagkau konsumen dari berbagai lapisan. Tidak hanya itu, melihat dari manfaat yang ditawarkan media sosial instagram memperlihatkan bahwa komunikasi bisnis dengan mengggunakan media sosial Instagram merupakan perpadaun antara New Media dan Marketing Communication. Melalui media sosial, Online Shop dapat menjagkau konsumen secara luas dan menjagkau semua lapisan masyarakat baik secara umur, pendidikan, dan penghasilan. Peluang pemanfaatan media sosial Instagram disadari oleh online shop Mantan Karyawan untuk memasarkan dan mengkomunikasikan produk nya melalaui Instagram. Dengan Instagram, online shope Mantan Karyawan bisa secara langsung menawarkan konsep, promosi, diskon, produk yang ditawakan melalui foto dan video yang membuat konsumen tertarik untuk menjadi follower dan membeli produk yang ditawarkan. 
Mantan Karyawan saat ini menjadi online shop yang diikuti atau memiliki follower mencapai 17,5 Ribu pengikut. Dalam sehari produk pakaian terjual mencapai 100 pcs bahkan sampai mencapai 150 pcs.Pertama, Promosi yang dilakukan seperti live streaming, video yang selalu terbaru mengenai produk, fotofoto produk pakaian.Kedua, Produk pakaian yang selalu terbaru dan memiliki banyak variasi.Ketiga, Price yang ditawarkan lebih murah dan sering memberikan diskon, selain itu harga grosir. Sehingga melalui marketing mix dalam mengkomunikasikan bisnis mampu menambah followers dan mendatangkan komsumen. Sehingga dengan berkembangnya online shope Mantan Karyawan dengan menggunakan instagram sebagai media publikasi dan promosi, sehingga mempermudah komunikasi bisnis bagi pemilik untuk bisa mengembangkan usahanya dan menambah followers.

Komunikasi bisnis online shopemantan karyawan dengan menggunakan media sosial instagram maka Konteks komunikasi yang tepat yaitu komunikasi bisniskarena Komunikasi Bisnis pada dasarnya sebuah proses pertukaran informasi serta pesan bisnis dalam membentuk sistem dan struktur organisasi yang kondusif dalam memaksimalkan efisiensi dan efektifitas produk kerja. Menurut Purwanto (2011), komunikasi bisnis meliputi berbagai bentuk komunikasi yang baik berupa komunikasi verbal maupun nonverbal yang memiliki tujuan tertentu untuk dicapai.

Tidak jauh berbeda menurut Rosenblatt, et al (1977) mendefinisikan komunikasi bisnis sebagai "pertukaran gagasan, pendapat, informasi, instruksi dan sebagainya yang memiliki tujuan tertentu yang disajikan secara personal atau impersonal melalui simbol-simbol atau sinyal-sinyal untuk mencapai tujuan organisasi".Dalam definisi tersebut, bila kita perhatikan secara seksama, mengandung 6 unsur pokok komunikasi bisnis, yaitu (1) bertujuan, berarti komunikasi bisnis harus memiliki tujuan yang telah ditetapkan sebelumnya sejalan dengan pencapaian tujuan organisasi/lembaga. Bisa saja tujuan komunikasi tersebut bersifat formal atau informal, tapi tidak bersifat sosial kecuali yang sejalan dengan tujuan utama organisasi/lembaga, (2) pertukaran, kegiatan ini melibatkan paling tidak dua orang atau lebih yakni komunikator dan komunikan, (3) gagasan, opini, informasi, instruksi merupakan isi dari pesan yang bentuknya beragam bergantung tujuan, situasi dan kondisinya, (4) saluran personal atau impersonal yang mungkin bersifat tatap muka atau siaran televisi yang menjangkau jutaan orang secara bersamaan, (5) simbol atau sinyal yang merupakan alat atau metode yang dapat dimengerti untuk menyampaikan atau mempertukarkan pesan. Simbol bisa bersifat positif atau abstrak; sinyal bisa berbentuk verbal atau nonverbal.Tapi yang terpenting adalah bagaimana pesan yang disampaikan bisa dimengerti dengan baik, (6) pencapaian tujuan organisasi.

Sama halnya yang dilakukan oleh Online ShopeMantan Karyawan, melakukan komunikasi bisnis melalui media sosial Instagram. Instagram merupakan media atau alat dalam mengkomunikasikan produk yang akan di pasarkan kepada konsumen. Pertama, Komunikasi bisnis berupa verbal dapat dilihat dari komunikasi pemilik online shope Mantan Karyawan dalam membuat live streaming di Instagram dengan menggunakan bahasa persuasif dengan memperlihatkan atau memperagakan produk di tambah dengan keterangan dengan diskon dan bahan yang digunakan. Tidak hanya itu dilengkapi dengan tulisan di beranda dengan dilengkapi dengan foto-foto produk 
yang menarik.Sehingga Komunikasi bisnis yang di lakukan melalui media sosial Instagram tepat digunakan untuk bisa menjangkau semua konsumen.

Level komunikasi yang digunakan dalam analisis ini adalah komunikasi massa. Menurut Littlejohn (2002) Komunikasi Massa adalah komunikasi yang berhubungan dengan publik atau masyarakat dan menggunakan media massa, yang merupakan suatu sarana mediasi dengan masyarakat tersebut. Griffin (2006) juga memberikan pengertian mengenai komunikasi massa, yaitu; komunikasi yang dilakukan dengan menggunakan media massa. Dari penjelasan tersebut dapat dipahami bahwa komunikasi massa merupakan komunikasi yang dilakukan dengan media massa sebagai sarana mediasi dan publikasi antar individu, kelompok atau organisasi/ perusahaan yang terkait dalam proses komunikasi tersebut.

Level komunikasi yang digunakan yaitu level komunikasi massa, karena penggunaan Instagram sebagai media promosi dalam mempublikasikan produk dari online shop Juragan Mode sangat membantu untuk bisa menjangkau seluruh konsumen yang di tuju. Tidak hanya itu, Instagram sebagai media atau alat promosi memberikan kemudahan bagi pemilik online shop untuk bisa mempublikasikan dan memperomosikan semua produk. Instagram sebagai media telah memfasilitasi pemilik Online Shop untuk bisa melakukan pemasaran secara langsung dengan cara membagikan video promosi, foto-foto, serta instastory dan live streaming yang dapat dilakukan secara gratis dan langsung.

Teori yang digunakan dalam analisis Komunikasi bisnis online shopeMantan Karyawan melalui media sosial instagram yaitu teori Marketing Mix dari Philip Kotler (2008), yang dikenal dengan 4P yaitu :

Produk (Product) $\rightarrow$ Segala sesuatu yang dapat ditawarkan kepada pasar untuk memuaskan suatu keinginan atau kebutuhan konsumen. Produk yang ditawarkan oleh online shop Mantan Karyawan dapat di update secara langsung melalui foto-foto terbaru, Live streaming, instastory, serta video semua produk.

Harga (Price) $\rightarrow$ Sejumlah uang yang mempunyai nilai tukar untuk memperoleh keuntungan dari memiliki atau menggunakan suatu produk atau jasa. Publikasi yangdilakukan melalaui media sosial Instagram, semua konsumen dapat mengetahui langsung harga dan diskon yang ditawarkan online shopMantan Karyawan.

Tempat $($ Place $) \rightarrow$ Tempat merupakan berbagai kegiatan yang dilakukan oleh perusahaan untuk membuat produk mudah diperoleh dan tersedia pada konsumen sasaran. Saat ini, dengan kemajuan teknologi, setiap individu bisa membuka toko secara online sehingga tidak hanya memiliki tempat penjualan secara real. Dengan media sosial instagram memberikan tempat untuk bisa mempromosikan produk.

Promosi(Promotion) $\rightarrow$ Promosi adalah semua kegiatan yang dilakukan perusahaan untuk mengkomunikasikan dan mempromosikan produk kepada pasar sasaran. Dengan Instagram, Promosi yang dilakukan online shopMantan Karyawan sangat di permudah, untuk bisa live streaming tidak harus membayar dan mengeluarkan biaya, selain itu pembuatan video dan di share ke semua followers bisa secara langsung dilakukan. Foto-foto terbaru bisa di update setiap saat. Artinya 
bahwa instagram sebagai media promosi telah mampu memberikan ruang untuk bisa mempromosikan semua produk.

\section{METODE PENELITIAN}

Penelitian ini menggunakan metode Kualitatif, dengan teknik pengumpulan data yaitu observasi, wawancara dan dokumentasi. Informan dalam penelitian ini adalah follower atau pengikut dari akun @Mantankaryawan yang melihat langsung kegiatan baik yang di share di Instagram melalui postingan dan siaran langsung story. Peneliti menggunakan rujukan melalui metode penelitian kualitaitf edisi revisi (Moleong, 2017).

\section{HASIL DAN PEMBAHASAN}

Media sosial Instagram telah mengubah budaya masyarakat, yang tadinya hanya berjualan secara konvensional tetapi telah menstimulus masyarakat untuk bisa menciptakan online shop di media sosial. Artinya dengan media sosial instagram telah merubah budaya masyarakat, yang sebelumnya membuka toko secara real, tetapi dengan instagram telah mempermudah masyarakat untuk bisa membuka online shop. Tidak hanya itu, tidak harus datang langsung ke toko, tetapi konsumen bisa langsung memesan dan menerima barang dirumah. Ditambah lagi pembayaran yang secara online semakin mempermudah konsumen dalam bertransaksi. Semua kemudahan yang ditawarkan oleh media sosial instagram, telah mempermudah komunikasi bisnis bagi penjual atau reseller. Promosi online shop dengan mudah bisa langsung memposting melalaui instastory yang langsung bisa tag atau menandai teman atau konsumen. Live streaming yang dapat dilakukan secara gratis, Kemudian foto-foto produk terbaru bisa di publis setiap saat ditambah lagi dengan price yang langsung di tawarkan lengkap dengan diskonnya.

Online Shop Mantan Karyawan, melakukan komunikasi bisnis melalui media sosial Instagram. Instagram merupakan media atau alat publikasi produk yang akan di pasarkan kepada konsumen. Pertama, Komunikasi bisnis berupa verbal dapat dilihat dari komunikasi pemilik online shope juragan mode dalam membuat live streaming di Instagram dengan menggunakan bahasa persuasif dengan memperlihatkan atau memperagakan produk di tambah dengan keterangan dengan diskon dan bahan yang digunakan. Tidak hanya itu dilengkapi dengan tulisan di beranda dengan dilengkapi dengan foto-foto produk yang menarik.Sehingga Komunikasi bisnis yang di lakukan melalui media sosial Instagram tepat digunakan untuk bisa menjangkau semua konsumen.

Teori yang digunakan dalam analisis Komunikasi bisnis online shope Mantan Karyawan melalui media sosial instagram yaitu teori Marketing Mix dari Philip Kotler (2008), yang dikenal dengan 4P yaitu: 1. Produk, Produk yang ditawarkan oleh online shop Mantan karyawan dapat di update secara langsung melalui foto-foto terbaru, Live streaming, instastory, serta video semua produk. 2. Price, Publikasi yangdilakukan melalaui media sosial Instagram, semua konsumen dapat mengetahui langsung harga dan diskon yang ditawarkan oleh online shopMantan Karyawan. 3. Place, kemajuan teknologi, setiap individu bisa membuka toko secara online tanpa harus memiliki tempat penjualan secara real. Dengan media sosial instagram 
memberikan tempat untuk bisa mempromosikan produk. 4. Promosi, Promosi yang dilakukan online shopMantan Karyawan sangat di permudah, untuk bisa live streaming tidak harus membayar dan mengeluarkan biaya, selain itu pembuatan video dan di share ke semua followers bisa secara langsung dilakukan. Foto-foto terbaru bisa di update setiap saat. Artinya bahwa instagram sebagai media promosi telah mampu memberikan ruang untuk bisa mempromosikan semua produk.

\section{SIMPULAN}

Berdasarkan Perkembangan Media baru saat ini, telah menstimulus masyarakat di daerah untuk bisa bersaing tidak hanya menciptakan toko secara konvensional tetapi toko secara online. Dalam penelitian ini, penulis menggunakan metode deskriptif kualitatif dilengkapi dengan referensi media online. Analisis komunikasi bisnis online shop mantan karyawan melalaui media sosial instagram dengan menggunakan pisau analisis yaitu Teori Marketing Mix dari Philip Kotler (2008:4),: 1. Produk, Produk yang ditawarkan oleh online shop Mantan karyawan dapat di update secara langsung melalui foto-foto terbaru, Live streaming, instastory, serta video semua produk. 2. Price, Publikasi yangdilakukan melalaui media sosial Instagram, semua konsumen dapat mengetahui langsung harga dan diskon yang ditawarkan oleh online shop Mantan Karyawan. 3. Place, kemajuan teknologi, setiap individu bisa membuka toko secara online tanpa harus memiliki tempat penjualan secara real. Dengan media sosial instagram memberikan tempat untuk bisa mempromosikan produk. 4. Promosi, Promosi yang dilakukan online shop Mantan Karyawan sangat di permudah, untuk bisa live streaming tidak harus membayar dan mengeluarkan biaya, selain itu pembuatan video dan di share ke semua followers bisa secara langsung dilakukan. Foto-foto terbaru bisa di update setiap saat. Artinya bahwa instagram sebagai media promosi telah mampu memberikan ruang untuk bisa mempromosikan semua produk.

\section{DAFTAR PUSTAKA}

APJII. (2019). Survei Pengguna Internet. Buletin APJII. Ed 74. November 2020

Ghony, M. D. \& Sari, T. R. (2012). Metode Penelitian Kualitatif. Jogjakarta: Ar-Ruzz Media

Griffin, EM. (2006). A First Look At Communication Theory, $6^{\text {ed }}$. Boston. McGrawHill

Kotler, P,. \& Armstrong, G. (2008). Prinsip-prinsip Pemasaran. Jilid 1. Jakarta. Erlangga

Littlejohn, S. W. (2002). Theories of Human Communication. $7^{\text {ed }}$. Belmont. CA. Wadsworth Publishing Company

Littlejohn, S. W \& Karen, A. F. (2009). Teori Komunikasi. Edisi 9. Jakarta. Salemba

Makkuraga, A. (2017). Penggunaan New Media sebagai Sarana Kampanye Politik Pada Kontestasi Pilkada Jabar 2018. Jurnal Visi Komunikasi, 16(2), 55-68 http://dx.doi.org/10.22441/jvk.v16i2.3805

Moelong, L. (2001). Metode Penelitian Kualitatif. Bandung. Remaja Rosdakarya

Nawawi, H. (1997). Metode Penelitian Bidang Sosial. Yogyakarta. Gadjah Mada University Press 
Morissan, M. (2013). Teori Komunikasi. Bogor. Ghalia Indonesia Pace

Morissan, M. (2011). Manajemen Media: Strategi Mengelola Radio dan Televisi. Jakarta. Prenada Media

Prayudha, H. (2005). Radio Suatu Pengantar untuk Wacana, dan Praktik Penyiaran. Malang. Bayumedia

Purwanto, D. (2006). Komunikasi Bisnis. Jakarta. Erlangga

Rohaniah, Y., \& Efriza. (2017). Handbook Sistem Politik Indonesia: Menjelajahi Teori dan Praktik. Malang. Intrans Publishing

Rosenblatt, S. (1977). Business Communication. Englewood Cliff, N.J. Prentice Hall.

Sukmadinata, S. (2006). Metode Penelitian Pendidikan. Bandung: Remaja Rosdakarya. Tabroni, R. (2012). Komunikasi Politik pada Era Multimedia. Bandung. Simbiosa Rekatama Media

Wardhani, D., \& Makkuraga, A. (ed). (2012). The Repotition of Communication In The Dynamic of Convergence: Reposisi Komunikasi dalam Dinamika Konvergensi. Jakarta. Kencana

Wayne, R., \& Faules, F. D. (2010). Komunikasi Organisasi Strategi Meningkatkan Kinerja Perusahaan, (Ed 7). Bandung. Rosdakarya 